\title{
BRPKM
}

Buletin Riset Psikologi dan Kesehatan Mental

http://e-journal.unair.ac.id/index.php/BRPKM

e-ISSN: 2776-1851

\section{Pengaruh Kesepian sebagai Salah Satu Faktor Risiko Pengalaman Psikotik pada Dewasa Awal}

\author{
ARINI MEILIA* \\ Fakultas Psikologi Universitas Airlangga
}

\begin{abstract}
ABSTRAK
Pengalaman psikotik merupakan bentuk dari simtom atau gejala psikotik (misal: delusi dan halusinasi) yang sifatnya lebih lemah yang tidak mencapai ambang batas klinis untuk diagnosis gangguan psikotik dan fenomena yang dapat terjadi pada populasi umum. Meskipun begitu, pengalaman psikotik juga diasosiakan dengan peningkatan risiko gangguan psikotik maupun nonpsikotik lainnya, serta berbagai kondisi mental negatif dan kualitas hidup yang lebih rendah. Penelitian ini bertujuan untuk mengetahui apakah kesepian berpengaruh sebagai salah satu faktor risiko pengalaman psikotik pada dewasa awal. Faktor risiko adalah sifat, karakteristik, atau ekspos apapun terhadap individu yang menigkatkan kecenderungan untuk mengembangkan sebuah gangguan Penelitian ini dilakukan pada 385 partisipan dewasa awal berusia 18-25 tahun. Alat ukur yang digunakan adalah Asesmen Komunitas terhadap Pengalaman Psikotik (AKPP) dan UCLA Loneliness Scale version 3. Hasil penelitian ini menunjukkan bahwa kesepian memiliki pengaruh sebagai salah satu faktor risiko pengalaman psikotik pada dewasa awal.
\end{abstract}

Kata kunci: dewasa awal, kesepian, pengalaman psikotik, psikotik kontinum

\begin{abstract}
The term 'psychotic experiences' are attenuated forms of psychotic symptoms (e.g delusions and hallucinations) that do not reach the clinical threshold for a psychotic disorder diagnosis and frequent in general population. However, psychotic experience is associated with an increase in other psychotic and nonpsychotic disorders, as well as various negative mental conditions and a lower quality of life. This study aims to determine whether loneliness has an effect as a risk factor for psychotic experiences in emerging adulthood. The risk factor is a trait, characteristic, or exposure to an individual that increases the tendency to develop a disorder. This study was conducted on 385 emerging adults aged 18-25 years. The measuring instruments used are Asesmen Komunitas terhadap Pengalaman Psikotik (AKPP) an UCLA Loneliness Scale version 3. The results of this study indicate that loneliness has an effect as one of the risk factors for psychotic experiences in early adulthood.
\end{abstract}

Keywords: emerging adulthood, loneliness, psychotic continuum, psychotic experience

Buletin Penelitian Psikologi dan Kesehatan Mental (BRPKM), 2021, Vol. 1(2), 1207-1217

*Alamat korespondensi: Fakultas Psikologi Universitas Airlangga, Kampus B Universitas Airlangga Jalan

Airlangga 4-6 Surabaya 60286. Surel: arini.meilia-2017@psikologi.unair.ac.id

Naskah ini merupakan naskah dengan akses terbuka dibawah ketentuan the Creative Common Attribution License (CC-BY-4.0) (http://creativecommons.org/licenses/by/4.0), sehingga penggunaan, distribusi, reproduksi dalam media apapun atas artikel ini tidak dibatasi, selama sumber aslinya disitir dengan baik. 


\section{P E N D A H U L U A N}

Masa dewasa awal, yang berkisar antara 18 hingga 34 tahun, merupakan tahap kehidupan yang krusial, dimana terdapat periode penyesuaian diri terhadap pola kehidupan yang baru dan harapan-harapan sosial baru. Individu dewasa awal diharapkan mulai melepaskan diri dari ketergantungan terhadap orangtua baik dalam aspek ekonomi, sosiologi, dan psikologi. Pada fase perkembangan ini terdapat eksplorasi individu terhadap nilai, ide, dan tujuan hidup yang diadopsi untuk mendefinisikan diri sendiri (Schwartz dkk., 2013). Maka, individu pada fase dewasa awal diharapkan terbebas dari gangguan mental, karena gangguan mental pada usia dewasa awal akan menghambat perkembangan psikologis, sosial, akademik maupun karir (Suvisaari dkk., 2009).

Secara global ditemukan prevalensi angka gangguan mental yang tinggi pada kelompok usia dewasa awal. Terdapat sebesar 52.4\% angka prevalensi gangguan mental diderita oleh individu dengan usia 18 hingga 29 tahun, dengan gangguan kecemasan paling banyak diderita sebesar $30.2 \%$, gangguan mood $21.4 \%$, dan gangguan penyalahgunaan zat 16,7\%. Sementara di Indonesia, pada penduduk berusia 15 tahun keatas ditemukan peningkatan angka prevalensi gangguan emosional dari 6\% di tahun 2013 menjadi 9,8\% di 2018, dan gangguan jiwa berat seperti skizofrenia meningkat dari 1,7\% di tahun 2013 hingga 7\% di tahun 2018 (Riskesdas, 2018). Prevalensi angka yang tinggi ini mengindikasikan bahwa masalah kesehatan mental banyak didominasi oleh kelompok dewasa awal (Kessler dkk., 2005).

Prevalensi gangguan mental yang tinggi pada kelompok usia dewasa awal juga konsisten dengan onset usia dini dari sebagian besar gangguan mental (Kim-Cohen dkk., 2003). Dikutip dari NCS-R, tiga perempat dari gangguan mental rata-rata muncul pada usia 24 tahun atau saat fase dewasa awal (Kessler dkk., 2005). Salah satu onset gangguan mental yang biasanya terjadi saat dewasa awal adalah gangguan psikotik. Setiap tahunnya terdapat sekitar 32 orang per 100.000 orang dewasa dan dewasa muda mengalami onset gangguan psikotik, dengan rata-rata kemunculan onset biasanya terjadi saat kisaran usia 15 hingga 25 tahun (Kirkbride dkk., 2012).

Simtom psikotik lebih banyak dialami oleh kelompok usia muda (Rössler, 2007; van Os \& Kapur, 2009). Kemunculan simtom psikotik pada kelompok usia muda dikaitkan dengan tugas perkembangan. Yung \& McGorry (1996) mengatakan kecenderungan ini terjadi saat individu sedang mengalami perkembangan kepribadian dan masalah mengenai identitas diri yang masih berusaha untuk diselesaikan. Sementara dari perspektif neuropsikologis, telah dihipotesiskan bahwa masa remaja akhir dan dewasa awal merupakan tahap perkembangan otak yang mendukung ekspresi klinis simtom psikotik pada penyakit kejiwaan atau neurologis (Verdoux dkk., 1998).

Psikotik merupakan kondisi medis yang terjadi akibat adanya disfungsi dalam otak. Pada dasarnya, istilah psikotik digunakan untuk mendeskripsikan kondisi mental individu ketika tidak terhubung dengan realita. Masalah distorsi realita tersebut disebabkan oleh adanya khayalan dan halusinasi, amotivasi untuk hidup, pikiran dan tata bahasa yang tidak terorganisir, dan perilaku psikomotor yang tidak normal (Association, 2013). Mengacu pada aturan diagnosis DSM-V, individu harus setidaknya memiliki lebih dari satu episode psikotik, bersamaan dengan kemunculan simtom-simtom lainnya selama 6 bulan berturut-turut untuk dikatakan memiliki gangguan psikotik (Association, 2013). Meskipun simtom psikotik sering kali dikaitkan dengan adanya gangguan, menariknya hal ini adalah hal yang umum terjadi di populasi umum. 
Di Indonesia, pengalaman psikotik adalah fenomena yang umum terjadi. Menurut hasil penelitian Jaya dan Wulandari (2018 dalam (Audinia, 2019), baik pengalaman positif dan negatif psikotik ditemukan pada populasi perkotaan dan nonperkotaan di Indonesia. Berdasarkan hasil penelitian Jaya dkk. (2020) mengenai perbandingan skor pengalaman psikotik negara berkembang dengan negara maju, didapati hasil bahwa Indonesia memiliki skor pengalaman psikotik lebih tinggi daripada negara maju. Beberapa jenis pengalaman psikotik yang skornya tinggi adalah pengalaman positif psikotik dengan dimensi pengalaman aneh dan pengalaman negatif dengan dimensi afek datar paling banyak muncul.

Dengan munculnya pengalaman psikotik pada populasi normal yang cukup umum, tentu dampaknya pada aspek kehidupan sehari-hari maupun fisik juga perlu diinvestigasi. Steenkamp dkk. (2020) menyebutkan bahwa pengalaman psikotik diasosikan dengan peningkatan risiko gangguan psikotik maupun nonpsikotik lainnya, serta berbagai kondisi mental negatif dan kualitas hidup yang lebih rendah. Pengalaman psikotik yang dialami individu dinilai berpotensi berdampak pada kehidupan sehari-hari karena kaitannya dengan status kesehatan yang lebih buruk (Nuevo dkk., 2012). Selain dampaknya pada kesehatan fisik, munculnya pengalaman psikotik pada populasi umum dikaitkan juga dengan risiko bunuh diri yang lebih tinggi, kinerja yang lebih buruk pada memori harian dan kelancaran verbal, serta keberfungsian yang berkurang (Guerrero-Jiménez, 2018). Selain itu, umumya pada pasien dengan gangguan psikotik biasa ditemukan permasalahan perilaku yang dilatarbelakangi oleh ketidakmampuan mereka dalam mengontrol dorongan dalam diri atau impulse (Compton \& Kaslow, 2005). Impulsivitas yang tinggi juga muncul pada sampel survey pengalaman psikotik pada populasi umum. Menurut Lee dkk. (2013 dalam (Guerrero-Jiménez, 2018), terdapat malfungsi di bagian anterior cingulate cortex otak pada individu yang mengalami pengalaman psikotik sehingga menurunkan kapasitas mereka dalam mengatur impuls, fungsi kognitif, dan memproses konflik.

Melalui paradigma kontinum psikotik diketahui bahwa simtom subklinis psikotik atau pengalaman psikotik dengan gangguan psikotik hanya berbeda dalam frekuensi simtom, tingkat keparahan atau peenderitaannya, dan apakah ditemukan komorbid dengan gangguan lain (Johns \& van Os, 2001). Baik simtom psikotik subklinis atau pengalaman psiktok dengan gangguan psikotik memiliki faktor risiko yang sama (Linscott \& van Os, 2013 dalam (Hermanto dkk., 2019). Jurnal Jaya dkk. (2017) menyebutkan, dalam penelitian psikologi, simtom psikotik erat kaitannya dengan beberapa faktor psikososial seperti pengalaman didiskriminasi, menjadi korban perundungan, tinggal di daerah perkotaan, tinggal sendirian, menjadi imigran, memiliki status sosioekonomi yang rendah, dan jaringan dan dukungan sosial yang rendah.

Menurut teori social defeat, kategori faktor risiko yang disebutkan diatas memiliki satu komponen yang sama, yakni adanya pengalaman negatif dikucilkan dari kelompok mayoritas atau eksklusi sosial yang dapat menyebabkan peningkatan aktivitas dasar dari sistem dopamin mesolimbik dimana hal ini dapat meningkatkan risiko skizofrenia atau psikotik (Selten dkk., 2013). Lebih lanjut lagi, Jaya dkk. (2017) berpendapat bahwa ada kesamaan lain dari kategori faktor social defeat yang belum disebutkan di atas, yakni kesepian. Pengalaman ini akan memicu persepsi bahwa mereka adalah individu yang terkucilkan atau diasingkan dari kelompok mayoritas, persepsi individu bahwa mereka telah terisolasi sosial adalah definisi dari kesepian sehingga perasaan kesepian diekpektasikan untuk muncul sebagai akibat dari kategori factor social defeat di atas. Dengan demikian, Jaya dkk. (2017) berpendapat bahwa kesepian dapat menjadi salah satu faktor risiko pengalaman psikotik pada individu.

Konstruk 'kesepian' memiliki makna yang sama dengan perceived social isolation, dan bukan pada objective social isolation (Hawkley \& Cacioppo, 2010). Adanya persepsi isolasi sosial yang dimiliki oleh individu kesepian dapat memberikan beban dan ancaman berlebih sehingga memunculkan persepsi bahwa dunia sosial sebagai hal yang mengancam sehingga individu tersebut membangun ingatan yang 
buruk terhadap dunia luar dan adanya ancaman berlebih akan cenderung membuat individu memfokuskan perhatian lebih pada impresi sosial yang bersifat negatif dan mengingat kejadian sosial adalah sesuatu yang dihindari (Hawkley \& Cacioppo, 2010). Tanpa disadari, terdapat bias kognitif yang memengaruhi proses informasi individu tersebut mengenai dunia luar. Kesepian akan mengakibatkan disfungsi kognitif dan menimbulkan persepsi yang buruk mengenai hubungan sosial. Individu yang kesepian akan terus mempertahankan rasa kesepiannya karena terdapat proses informasi sosial yang bias dan menghasilkan persepsi negatif terhadap hubungan sosial (Leary, 1990).

Akibatnya penilaian kognitif individu yang negatif cenderung memunculkan tingkah laku menarik diri dari sosial sehingga membatasi kesempatan individu untuk merasakan pengalaman positif dari interaksi hubungan sosial (Qualter dkk., 2015). Tingkah laku menarik diri sosial merupakan bagian dari simtom negatif psikotik, dan persepsi konsisten mengenai dunia dan orang lain yang mengancam adalah paranoid yakni bagian dari simtom positif psikotik. Penjelasan ini sejalan dengan teori cognitive model of psychosis: persepsi yang konsisten mengenai orang lain akan selalu mengancam dirinya, dan tentang dunia luar adalah tempat yang berbahaya, akan meningkatkan simtom psikotik (Garety, 2000).

Kesepian merupakan isu yang relevan dalam topik psikosis. Kesepian dapat memengaruhi kemunculan gejala psikotik khususnya pada gejala halusinasi dan kepercayaan atas persekusi (persecutory beliefs) dan paranoid. Menurut Freeman dkk. (2005 dalam Jaya dkk. 2017) gejala paranoid berasal dari kekhawatiran terhadap evaluasi sosial. Baik gejala paranoid maupun halusinasi timbul dari kurangnya input sosial yang bermakna atau input sosial yang justru memaksa memperbaiki diri secara terusmenerus.

Berdasarkan uraian diatas, ditemukan permasalahan bahwa masa dewasa awal sering dikatakan sebagai periode puncak kerentanan bagi individu untuk mengekspresikan simtom psikotik dan menurut paradigma kontinum psikotik simtom psikotik banyak terjadi di bawah ambang batas klinis atau istilah ini dirujuk sebagai pengalaman psikotik. Kesepian disinyalir sebagai salah satu faktor risiko yang berpotensi memunculkan tidak hanya pengalaman psikotik namun juga simtom psikotik, namun penelitian psikotik masih banyak memfokuskan jumlah koneksi yang dimiliki, dibandingkan dengan segi kualitatif suatu hubungan yang lebih fungsional seperti kepuasan terhadap hubungan, ada atau tidaknya orang lain yang dipercaya, atau kesepian (Gayer-Anderson dkk.,2013 dalam (Michalska da Rocha dkk., 2018).

Beberapa dari penelitian mengenai faktor risiko kesepian dengan pengalaman psikotik masih membahas uji korelasi. Uji korelasi berarti belum diketahui variabel mana yang berperan memengaruhi variabel lain sehingga bisa saja tingginya tingkat kesepian seseorang diakibatkan oleh pengalaman psikotik yang dirasakan. Sehingga peneliti tertarik untuk menguji pengaruh kesepian sebagai salah satu faktor yang dapat memengaruhi pengalaman psikotik pada dewasa awal.

\section{Desain Penelitian}

\section{E T O D E}

Tipe penelitian ini adalah kuantitatif-eksplanatori dengan desain penelitian cross-sectional yakni penelitian diambil dalam satu waktu. Teknik pengambilan data dilakukan dengan survei berisi closeended questions dimana partisipan akan memilih jawaban yang penulis sediakan. 


\section{Partisipan}

Partisipan dalam penelitian ini terdiri dari dewasa awal dalam rentang usia 18 hingga 25 tahun yang tersebar di seluruh wilayah Indonesia. Teknik sampling yang diaplikasikan dalam penelitian ini adalah teknik random sampling dimana penelitian ini tidak memiliki kriteria khusus dan memberikan setiap individu dari populasi mendapatkan kesempatan yang sama untuk dipilih. Metode pengambilan sampel dilakukan secara random karena akan mengukur pengalaman psikotik dewasa awal pada populasi umum. Penentuan jumlah sampel minimal $(N \geq 119)$ didapatkan berdasarkan perhitungan oleh perangkat lunak $G^{*}$ Power $(1-\beta=0.8, \alpha=0.05, \rho=0.3)$. Seluruh partisipan penelitian telah mengisi lembar informed consent pada halaman awal survei daring yang dilakukan lewat google form.

\section{Pengukuran}

Penelitian ini mengukur dua variabel yakni kesepian sebagai variabel independent dan pengalaman psikotik sebagai variabel dependen. Variabel pengalaman psikotik pada penelitian ini diukur menggunakan Asesmen Komunitas terhadap Pengalaman Psikotik (AKPP) yang diadaptasi oleh Jaya (2017) ke dalam Bahasa Indonesia dari alat ukur Community Assesment of Psychotic Experience (CAPE) milik (Stefanis dkk., 2002). Alat ukur ini memiliki total 42 aitem dengan dimensi positif, negatif, dan depresif. Penelitian ini hanya menggunakan dimensi simtom positif dan negatif dengan total 34 aitem dengan 4 pilihan jawaban yakni (1= 'tidak pernah', 2= 'kadang-kadang', 3= 'sering', dan 4= 'hampir selalu). Skor tertinggi dari pengalaman psikotik dalam penelitian ini mencapai 122 dan skor terendah adalah 42. Reliabilitas alat ukur AKPP termasuk dalam kategori baik $(\alpha=0.90)$ pada dimensi simtom positif dan $(\alpha=0,88)$ pada dimensi simtom negatif. Selain itu, AKPP memiliki nilai validitas konstruk yang baik $(\mathrm{CFI}=0,852$, RMSEA=0,055, dan SRMR=0,060).

Alat ukur yang digunakan untuk mengukur kesepian adalah UCLA Loneliness Scale version 3 oleh Russel (1996). UCLA Loneliness Scale version 3 adalah alat ukur unidimensional yang memiliki total 20 aitem dan telah diterjemahkan ke dalam Bahasa Indonesia dengan pilihan jawaban yang tersedia yakni $(1=$ 'tidak pernah', 2= 'jarang', 3= 'kadang-kadang', 4= 'selalu). UCLA Loneliness Scale version 3 ini merupakan alat ukur yang sangat reliabel $(\alpha=0,92)$. Skor tertinggi yang didapatkan dalam penelitian ini mencapai 73 dan skor terendah adalah 20. Dalam penelitian ini uji asumsi parametrik telah terpenuhi mulai dari uji normalitas, linearitas, dan heterokedastisitas hingga uji regresi untuk membuktikan hipotesis dalam penelitian ini.

\section{Analisis Data}

Teknik analisis data yang dilakukan dimulai dari uji asumsi parametrik (normalitas dan linearitas) dan uji heterokedastisitas hingga uji regresi sederhana untuk mengetahui perngaruh variabel independent terhadap satu variabel dependen. Seluruh jenis teknik analisis dilakukan dengan bantuan perangkat lunak IBM SPSS Statistics 25 for Windows.

\section{HAS IL PENELITIAN}

Penulis melakukan analisis deskriptif guna mengetahui gambaran statistik data dalam penelitian ini. Hasil analisis deskriptif menunjukkan bahwa variabel pengalaman psikotik memiliki $(M=68,37$, $S D=14,261 ; M i n=42, M a x=122$ ) yang mengindikasikan rata-rata partisipan berada dalam rentang skor kategori rendah. Sementara, hasil analisis deskriptif pada variabel kesepian memiliki nilai $(M=48,60$, $S D=10,118$; $M i n=21, M a x=73$ ) dimana hal ini mengindikasikan skor rata-rata partisipan penelitian ini berada pada kategori sedang. 
Hasil analisis korelasi diketahui bahwa kesepian berkorelasi positif dan kuat dengan pengalaman psikotik ( $p=0,000 ; r=0,510)$. Selain itu, diantara seluruh dimensi pengalaman positif psikotik, kesepian memiliki hubungan paling kuat dengan subdimensi paranoia/paranoid.

Teknik analisis regresi dilakukan dalam penelitian ini untuk melihat pengaruh kesepian terhadap pengalaman psikotik. Berdasarkan hasil uji regresi linear sederhana pada IBM SPSS 25 for Windows, kesepian adalah salah satu faktor risiko yang memiliki pengaruh signifikan terhadap pengalaman psikotik $\left(p=0,000 ; R^{2}=0,260\right)$. Hal ini berarti kesepian memengaruhi kemunculan pengalaman psikotik sebesar 26\% dan 74\% lainnya berasal dari faktor lain yang tidak diteliti dalam penelitian ini.

Selain itu, kesepian merupakan salah satu faktor risiko yang berpengaruh terhadap dimensi pengalaman positif maupun negatif psikotik. Pada dimensi pengalaman positif psikotik besaran persentase kesepian terhadap pengalaman positif psikotik adalah 5,5\% $\left(p=0,000 ; R^{2}=0,055\right)$. Kesepian juga merupakan salah satu faktor risiko yang memiliki efek paling kuat terhadap paranoia dibandingkan dengan subdimensi lain dari dimensi pengalaman positif psikotik $\left(p=0,000 ; R^{2}=0,171\right)$. Sementara, besaran persentase kesepian terhadap pengalaman negatif psikotik adalah $31,1 \%\left(p=0,000 ; R^{2}=0,311\right)$.

\section{I S K U S I}

Berdasarkan analisis data yang dilakukan, kesepian merupakan salah satu faktor risiko yang berhubungan signifikan dengan pengalaman psikotik pada dewasa awal. Hubungan kesepian dan pengalaman psikotik ini bersifat positif yang memiliki makna bahwa semakin tinggi kesepian suatu individu maka akan semakin tinggi pengalaman psikotiknya. Hasil penelitian korelasi yang signifikan ini sejalan dengan penelitian metaanalisis yang dilakukan oleh Michalska da Rocha dkk. (2018), Chau (2019), dan juga penelitian Narita dkk. (2020). Kemudian, hasil analisis regresi menunjukkan kesepian merupakan salah satu faktor risiko yang berpengaruh secara signifikan terhadap pengalaman psikotik dimana kesepian memengaruhi kemunculan pengalaman psikotik sebesar $26 \%$ dan $74 \%$ lainnya berasal dari faktor lain yang tidak diteliti dalam penelitian ini.

Menurut teori cognitive model of psychosis, hubungan kesepian dengan pengalaman negatif maupun positif psikotik dapat diperjelas lewat peran self-concept dan self-esteem yang dimiliki oleh individu yang mempersepsikan kesepian. Hal ini dikarenakan persepsi kesepian yang dialami individu akan memperkuat self-concept yang sifatnya negatif serta selanjutnya berdampak secara negatif pada selfesteem. Kemudian, adanya self-concept dan self-esteem yang negatif ini akan berperan dalam memunculkan pemikiran maladaptif atau menyimpang mengenai diri sendiri maupun orang lain (Trower \& Chadwick, 1995).

Contoh-contoh penyimpangan pemikiran mengenai diri sendiri maupun orang lain yang dimiliki oleh individu yang kesepian adalah: anggapan bahwa individu adalah orang yang berbeda dan tidak biasa, orang lain adalah musuh yang membenci, dan dunia atau lingkungan sosial adalah tempat yang membahayakan. Pemikiran seperti ini secara khas dimiliki oleh individu yang mengalami kesepian, dimana argumen ini juga didukung oleh (Heinrich \& Gullone, 2006). Model of Loneliness: Hypervigilance to Social Threat yang dikemukakan oleh Hawkley \& Cacioppo (2010) turut mendukung argument sebelumnya, teori ini menjelaskan bahwa individu yang merasa kesepian pada dasarnya mempersepsikan dirinya terisolasi secara sosial dimana hal ini memicu individu untuk memiliki perasaan tidak aman yang menetap dan memicu kewaspadaan berlebih untuk mengantisipasi ancaman sosial yang datang dari lingkungan sosialnya.

Tidak hanya itu, antisipasi berlebih ini juga disebabkan karena individu yang mengalami kesepian cenderung memiliki kemampuan sosial yang buruk (Heinrich \& Gullone, 2006). Selanjutnya, menurut 
Audinia (2019) beberapa perilaku yang menunjukkan kemampuan sosial yang rendah pada orang kesepian antara lain kesulitan membangun hubungan sosial di lingkungan baru dan berteman dengan orang lain. Karena kemampuan sosial yang rendah, individu yang merasa kesepian akan mempersepsikan interaksi sosial sebagai hal yang negatif, dan lebih banyak mengingat informasi sosial yang sifatnya negatif sehingga melihat dunia sosial sebagai tempat yang lebih mengancam. Dengan demikian, perilaku menarik diri muncul sebagai cara bagi individu yang kesepian untuk memproteksi diri dari ancaman sosial. Perilaku menarik diri membuat individu membatasi kesempatan untuk merasakan pengalaman positif dari interaksi hubungan sosial (Qualter dkk., 2015).

Tingkah laku menarik diri dari lingkungan sosial merupakan bagian dari pengalaman psikotik yang lebih spesifik yakni simtom negatif psikotik, dan persepsi konsisten mengenai dunia dan orang lain yang mengancam dapat dikatakan sebagai paranoia yakni bagian dari pengalaman positif psikotik. Penjelasan ini sejalan dengan teori sebelumnya, yakni cognitive model of psychosis: persepsi yang konsisten mengenai orang lain akan selalu mengancam dirinya, dan tentang dunia luar adalah tempat yang berbahaya, akan meningkatkan pengalaman psikotik baik pengalaman positif psikotik maupun negatif psikotik (Garety, 2000).

Pada dua teori sebelumnya telah dijelaskan bahwa kesepian akan mengakibatkan individu cenderung membatasi hingga menarik diri dari lingkungan sosial. Selanjutnya, kurangnya kontak sosial dengan orang lain pada individu yang mempersepsikan kesepian akan memicu kondisi 'kebosanan dan kekosongan (Weiss, 1983 dalam (Audinia, 2019). Telah diketahui bahwa individu yang mempersepsikan perasaan kesepian melihat dunia sosial sebagai hal yang mengancam dan menghindar dari lingkungan sosial sehingga menurut teori social deafferentation theory milik Hoffman (2007) individu akan mengkompensasi kekosongan terebut dengan membuat stimulus internal. Teori social deafferentation menjelaskan bahwa delusi dan halusinasi merupakan akibat dari aktivitas jaringan pada social brain yang hiperaktif yang dipicu oleh adanya isolasi sosial yang bekepanjangan pada individu yang memiliki faktor kerentanan. Social brain yang dimaksud adalah domain pada otak manusia yang berfungsi untuk memahami percakapan, aspek emosi, niat, intensi, dan kondisi pikiran orang lain pada saat interaksi sosial berlangsung (Hoffman, 2007).

Pada saat individu membatasi interaksi sosial dalam waktu yang cukup lama, maka social brain tersebut akan kekurangan masukan dari pengalaman sosial yang sebenarnya, ketika ini terjadi maka bagian otak tersebut akan cenderung membuat kontak sosial sendiri dalam bentuk halusinasi dan delusi (Jaya dkk., 2017). Dalam jurnalnya, Jaya dkk. (2017) menjelaskan teori yang dijelaskan ini mirip dengan sindrom phantom limb, ketika individu masih merasakan sensasi pada tangan yang telah diamputasi. Fenomena ini terjadi karena otak masih menerima pesan dari syaraf yang dulu terkoneksi dengan tangan yang hilang. Fenomena yang sama terjadi pada otak manusia ketika kekurangan input sosial, otak akan memunculkan kontak sosial dari dalam diri sendiri dalam bentuk halusinasi dan delusi (Van der Steen, 2018).

Sementara faktor kerentanan yang dimaksud oleh Hoffman (2007) adalah faktor-faktor yang meningkatkan kerentanan individu dalam memunculkan gejala psikotik. Salah satu faktor kerentanan yng dibahas oleh Hoffman dalam jurnalnya ini adalah berada dalam periode remaja akhir hingga dewasa awal, rentang usia ini juga disebut oleh Arnett (2014) sebagai emerging adulthood. Periode ini dikatakan Hoffman (2007) sebagai vulnerable period for schizophrenia.

Periode tersebut dikatakan sebagai periode yang rentan akan pengembangan gejala psikotik maupun gangguan psikotik. Apabila individu menarik diri dari lingkungan sosial selama periode kritis perkembangan, maka akan menghasilkan gangguan dalam sel syaraf dalam penyusunan bagian di 
korteks asosiasi yang berperan dalam kognisi sosial yang akhirnya berujung pada pemaknaan sosial (Hoffman, 2007). Masih dari perspektif neuropsikologis, hal yang sama juga diutarakan oleh Verdoux dkk. (1998) bahwa masa remaja akhir dan dewasa awal merupakan tahap perkembangan otak yang mendukung ekspresi klinis gejala psikotik pada penyakit kejiwaan atau neurologis.

\section{S I M P U L A N}

Berdasarkan hasil analisis data yang telah dilakukan dalam penelitian ini, maka dapat disimpulkan bahwa kesepian adalah salah satu faktor risiko yang memiliki pengaruh signifikan terhadap pengalaman psikotik pada usia dewasa awal. Hubungan kesepian dengan pengalaman psikotik bersifat positif sehingga apabila nilai kesepian individu meningkat, maka skor pengalaman psikotik pun meningkat. Selain itu, penelitian ini juga menemukan bahwa kesepian adalah faktor risiko yang memiliki pengaruh lebih besar terhadap dimensi pengalaman negatif psikotik dibandingkan pengalaman positif psikotik.

Penelitian ini memiliki keterbatasan sehingga penulis menyarankan bagi penelitian selanjutnya untuk menambahkan variabel independent berupa faktor-faktor yang dapat meningkatkan risiko meningkatnya pengalaman psikotik untuk memperkaya penelitian mengenai pengalaman psikotik, dan menambahkan variabel mediator dan/atau moderator lain sehingga dapat diketahui interaksi maupun penyebab kemunculan pengalaman psikotik yang lebih detail. Penelitian selanjutnya diharapkan dapat meningkatkan variabilitas partisipan dengan tidak hanya melakukan penelitian secara daring.

Bagi individu dewasa awal disarankan untuk dapat berlatih menunjukkan lebih banyak emosi positif yang memberikan sinyal keterbukaan pada orang lain, dan berlatih untuk melibatkan diri dengan orang lain dengan cara yang lebih prososial seperti menunjukkan kebaikan dan memberikan tanggapan yang aktif-konstruktif. Hal ini dapat dilakukan karena kemampuan interpersonal yang positif ini dapat membantu membangun keintiman dengan orang lain yang dapat mencegah timbulnya persepsi kesepian pada individu dewasa awal. Terakhir, dikarenakan hubungan antara kesepian dengan pengalaman psikotik dapat melibatkan pemrosesan informasi yang bias atau bias kognitif, self-esteem, self-concept individu yang kesepian. Hal ini menunjukkan urgensi untuk menjadikan skema individu, konsep diri, dan self-esteem sebagai target intervensi dan terapi. Tidak hanya itu, Psikolog dapat pula memberikan intervensi yang didesain untuk merustrukturisasi kognitif atau pemikiran maladaptif individu mengenai bagaimana perasaan dan penilaian individu tentang hubungan interpersonal yang dimiliki. Restrukturisasi kognitif bisa dilakukan dengan pendekatan strength-based intervention and positive psychotherapy untuk mepromosikan perasaan positif pada individu yang mempersepsikan kesepian.

\section{U C A P A N T ER I MAKASIH}

Penulis mengucapkan terima kasih kepada Tuhan Yang Maha Esa atas segala nikmat dan rahmat yang telah dilimpahkan kepada penulis, kepada dosen pembimbing penulis Dr. Hamidah, M.Si., Psikolog, kepada orang tua penulis, serta kepada semua yang bersedia menjadi partisipan dalam penelitian ini.

\section{DEKLARASI POTENSI TERJADINYA KONFLIK KEPENTINGAN}

Arini Meilia tidak bekerja, menjadi konsultan, memiliki saham, atau menerima dana dari perusahaan atau organisasi manapun yang mungkin akan mengambil untung dari diterbitkannya naskah ini. 


\section{PUST AKA ACUAN}

Arnett, J. J. (2014). Presidential Address: The Emergence of Emerging Adulthood: A Personal History. SAGE Journals. https://doi.org/10.1177/2167696814541096

Association, A. P. (2013). Diagnostic and Statistical Manual of Mental Disorder Edition "DSM 5." American Psychiatric Publishing.

Audinia, S. (2019). Hubungan Kesepian dan Gejala Psikotik: Peran Skema Negatif Sebagai Mediator. LibUI, 17-19.

Chau, A. K. W. (2019). Loneliness and the psychosis continuum: A meta-analysis on positive psychotic experiences and a meta-analysis on negative psychotic experiences. International Review of Psychiatry, 1-20. https://doi.org/10.1080/09540261

Compton, M. T., \& Kaslow, N. J. (2005). Self-reported psychotic symptoms predict impulsivity among African-American patients in an urban non-psychiatric medical setting. Psychiatry Research, 135(1), 35-44. https://doi.org/10.1016/j.psychres.2005.03.004

Garety, F. D. (2000). Cognitive approaches to delusions: A critical review of theories and evidence. Brit. J. Clin. Psych., 1999, 38(1), 13-54. https://doi.org/10.1348/014466599162700

Guerrero-Jiménez, M. G. B. C. G. (2018). A cross-sectional survey of psychotic symptoms in the community: The GRANAD $\sum$ P psychosis study. The European Journal of Psychiatry, 87-96.

Hawkley, L., \& Cacioppo, J. (2010). Loneliness matters: A theoritical and empirical review of consequences and mechanisms. Annals of Behavioral Medicine, 40(2), 218-227. https://doi.org/10.1007/s12160-010-9210-8

Heinrich, L. M., \& Gullone, E. (2006). The clinical significance of loneliness: A literature review. Clinical Psychology Review, 26(6), 695-718. https://doi.org/10.1016/j.cpr.2006.04.002

Hermanto, E., Asih, S. R., \& Jaya, E. S. (2019). The role of perceived discrimination in mediating the relationship between minority status and psychotic symptoms in a community sample. Konselor, 8(4), 104-112. https://doi.org/10.24036/0201983105924-0-00

Hoffman, R. E. (2007). A Social Deafferentation Hypothesis for Induction of Active Schizophrenia. Schizophrenia Bulletin, 33(5), 1066-1070. https://doi.org/10.1093/schbul/sbm079

Jaya, E. S., Hillmann, T. E., Reininger, K. M., Gollwitzer, A., \& Lincoln, T. M. (2017). Loneliness and psychotic symptoms: The mediating role of depression. Cognitive Therapy and Research, 41(1), 106-116. https://doi.org/10.1007/s10608-016-9799-4

Jaya, E. S., Wüsten, C., Alizadeh, B. Z., Amelsvoort, T. van, Bartels-Velthuis, A. A., Beveren, N. J. van, Bruggeman, R., Cahn, W., Haan, L. de, Delespaul, P., Luykx, J. J., Myin-Germeys, I., Kahn, R. S., Schirmbeck, F., Simons, C. J. P., Haren, N. E. van, Os, J. van, Winkel, R. van, Fonseca-Pedrero, E., ... Lincoln, T. M. (2020). Comparing psychotic experiences in low-and-middle-income-countries 
and high-income-countries with a focus on measurement invariance. Psychological Medicine, 18. https://doi.org/10.1017/S0033291720003323

Johns, L. C., \& van Os, J. (2001). The continuity of psychotic experiences in the general population. Clinical Psychology Review, 21(8), 1125-1141. https://doi.org/10.1016/s0272-7358(01)00103-9

Kessler, R. C., Berglund, P., Demler, O., Jin, R., Merikangas, K. R., \& Walters, E. E. (2005). Lifetime Prevalence and Age-of-Onset Distributions of DSM-IV Disorders in the National Comorbidity Survey Replication. Archives of General Psychiatry, 62(6), 593-602. https://doi.org/10.1001/archpsyc.62.6.593

Kim-Cohen, J., Caspi, A., Moffitt, T. E., Harrington, H., Milne, B. J., \& Poulton, R. (2003). Prior Juvenile Diagnoses in Adults With Mental Disorder: Developmental Follow-Back of a ProspectiveLongitudinal Cohort. Archives of General Psychiatry, 60(7), 709-717. https://doi.org/10.1001/archpsyc.60.7.709

Kirkbride, J. B., Errazuriz, A., Croudace, T. J., Morgan, C., Jackson, D., Boydell, J., Murray, R. M., \& Jones, P. B. (2012). Incidence of Schizophrenia and Other Psychoses in England, 1950-2009: A Systematic $\begin{array}{lllll}\text { Review and } \quad \text { Meta-Analyses. PLOS } & \text { 7(3), }\end{array}$ https://doi.org/10.1371/journal.pone.0031660

Leary, M. R. (1990). Responses to social exclusion: Social anxiety, jealousy, loneliness, depression, and low self-esteem. J Soc Clin Psychol, 9(2):221-229.

Michalska da Rocha, B., Rhodes, S., Vasilopoulou, E., \& Hutton, P. (2018). Loneliness in Psychosis: A Metaanalytical Review. Schizophrenia Bulletin, 44(1), 114-125. https://doi.org/10.1093/schbul/sbx036

Narita, Z., Stickley, A., \& DeVylder, J. (2020). Loneliness and psychotic experiences in a general population sample. Schizophr Res. Pubmed.gov. https://doi.org/10.1016/j.schres.2020.01.018

Nuevo, R., Chatterji, S., Verdes, E., Naidoo, N., Arango, C., \& Ayuso-Mateos, J. L. (2012). The Continuum of Psychotic Symptoms in the General Population: A Cross-national Study. Schizophrenia Bulletin, 38(3), 475-485. https://doi.org/10.1093/schbul/sbq099

Qualter, P., Vanhalst, J., Harris, R., Van Roekel, E., Lodder, G., Bangee, M., Maes, M., \& Verhagen, M. (2015). Loneliness Across the Life Span. Perspectives on Psychological Science, 10(2), 250-264. https://doi.org/10.1177/1745691615568999

Riset Kesehatan Dasar (Riskesdas) | Badan Penelitian dan Pengembangan Kesehatan (Riset Kesehatan Dasar). (2018). Badan Penelitian dan Pengembangan Kesehatan. https://www.litbang.kemkes.go.id/laporan-riset-kesehatan-dasar-riskesdas/

Russell, D. W. (1996). UCLA Loneliness Scale (Version 3): Reliability, Validity, and Factor Structure. 66(1), 20-40. https://doi.org/10.1207/s15327752jpa6601_2

Schwartz, S. J., Donnellan, M. B., Ravert, R. D., Luyckx, K., \& Zamboanga, B. L. (2013). Identity development, personality, and well-being in adolescence and emerging adulthood: Theory,

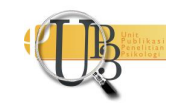


research, and recent advances. Dalam Handbook of psychology: Developmental psychology, Vol. 6, 2nd ed (hlm. 339-364). John Wiley \& Sons, Inc.

Selten, J.-P., van der Ven, E., Rutten, B. P. F., \& Cantor-Graae, E. (2013). The Social Defeat Hypothesis of Schizophrenia: An Update. Schizophrenia Bulletin, 39(6), 1180-1186. https://doi.org/10.1093/schbul/sbt134

Steenkamp, L. R., Bolhuis, K., Blanken, L. M. E., Luijk, M. P. C. M., Hillegers, M. H. J., Kushner, S. A., \& Tiemeir, H. (2020). Psychotic experiences and future school performance in childhood: A population-based cohort study. The Journal of Child and Psychology Psychiatry. https://doi.org/10.1111/jcpp.13281

Stefanis, N. C., Hanssen, M., Smirnis, N. K., Avramopoulos, D. A., Evdokimidis, I. K., Stefanis, C. N., Verdoux, H., \& Os, J. V. (2002). Evidence that three dimensions of psychosis have a distribution in the general population. Psychological Medicine, 32(2), 347-358. https://doi.org/10.1017/S0033291701005141

Suvisaari, J., Aalto-Setälä, T., Tuulio-Henriksson, A., Härkänen, T., Saarni, S. I., Perälä, J., Schreck, M., Castaneda, A., Hintikka, J., Kestilä, L., Lähteenmäki, S., Latvala, A., Koskinen, S., Marttunen, M., Aro, H., \& Lönnqvist, J. (2009). Mental disorders in young adulthood. Psychol Med . https://doi.org/10.1017/S0033291708003632.

Trower, P., \& Chadwick, P. (1995). Pathways to defense of the self: A theory of two types of paranoia. Clinical Psychology: Science and Practice, 2(3), 263-278. https://doi.org/10.1111/j.14682850.1995.tb00044.x

Van der Steen, Y. C. (2018). Dissecting the psychosis continuum: Risk factors along the pathway from experiences to disorder. Maastricht University.

van Os, J., \& Kapur, S. (2009). Schizophrenia. The Lancet, 374(9690), 635-645. https://doi.org/10.1016/s0140-6736(09)60995-8

Verdoux, H., van Os, J., Maurice-Tison, S., Gay, B., Salamon, R., \& Bourgeois, M. (1998). Is early adulthood a critical developmental stage for psychosis proneness? A survey of delusional ideation in normal subjects. Schizophrenia Research, 29(3), 247-254. https://doi.org/10.1016/S09209964(97)00095-9

Yung, A. R., \& McGorry, P. D. (1996). The prodromal phase of first-episode psychosis: Past and current $\begin{array}{llll}\text { conceptualizations. } & \text { Schizophrenia } & \text { Bulletin, } & \text { 22(2), }\end{array}$ https://doi.org/10.1093/schbul/22.2.353 